\title{
Response of early soybean cultivars to nitrogen fertilization associated with Bradyrhizobium japonicum inoculation ${ }^{1}$
}

\author{
Alan Mario Zuffo², Fábio Steiner³, Aécio Busch³, Tiago Zoz ${ }^{3}$
}

\section{ABSTRACT}

In early soybean cultivars of high productive potential, the use of chemical nitrogen $(\mathrm{N})$ fertilizer may be a critical factor to meet the crop $\mathrm{N}$ requirements for obtaining high yields. In order to determine the response of early soybean cultivars to doses and times of nitrogen fertilizer application, associated with the inoculation of Bradyrhizobium japonicum, two field experiments were conducted in a Quartzipsamment soil from the Brazilian tropical Savannah, during the 2016/2017 and $2017 / 2018$ growing seasons. The experimental treatments were arranged in a $2 \times 3 \times 4$ factorial scheme, being two soybean cultivars (BRS 1074 IPRO and ST 797 IPRO), three application times of $\mathrm{N}$ fertilizer (sowing, 30 and 50 days after the emergence) and four $\mathrm{N}$ doses $\left(0 \mathrm{~kg} \mathrm{ha}^{-1}, 20 \mathrm{~kg} \mathrm{ha}^{-1}, 40 \mathrm{~kg} \mathrm{ha}^{-1}\right.$ and $\left.60 \mathrm{~kg} \mathrm{ha}^{-1}\right)$. The following variables were evaluated: plant height, shoot dry matter, number of nodules, nodule dry matter, first pod height, number of pods, number of grains per pod, 1,000-grain mass, grain yield and harvest index. The use of $\mathrm{N}$ fertilizer did not improve the production components and did not increase the soybean grain yield, regardless of the doses and times of application. Therefore, it was concluded that, if efficient strains of B. japonicum are used in areas of first soybean crop, in a Quartzipsamment soil with medium-high fertility, especially with a relatively high $\mathrm{N}$ availability due to the mineralization of the soil organic matter, there is no need to apply starter or late doses of nitrogen fertilizer.

KEYWORDS: Glycine $\max$ L. Merrill; biological nitrogen fixation; urea; nodulation.

\section{INTRODUCTION}

Soybean [Glycine max (L.) Merrill.] is one of the essential oil crops in the world, especially due to the high amount of seed protein (36-40\%) and oil content (18-20\%) (Lima et al. 2015). The crop has a large nutrient requirement throughout

\section{RESUMO}

Resposta de cultivares de soja precoce a adubação nitrogenada associada à inoculação com Bradyrhizobium japonicum

Em cultivares de soja precoce de alto potencial produtivo, a adubação nitrogenada pode ser um fator crítico às exigências de nitrogênio $(\mathrm{N})$ da cultura para a obtenção de altas produtividades. Objetivando-se determinar a resposta de cultivares de soja precoce a doses e épocas de aplicação de $\mathrm{N}$, associada à inoculação de Bradyrhizobium japonicum, dois experimentos foram conduzidos em Neossolo Quartzarênico do Cerrado brasileiro, durante as safras de $2016 / 2017$ e $2017 / 2018$. Os tratamentos experimentais foram arranjados em esquema fatorial $2 \times 3 \times 4$, sendo duas cultivares de soja (BRS 1074 IPRO e ST 797 IPRO), três épocas de aplicação do fertilizante nitrogenado (semeadura, 30 e 50 dias após a emergência) e quatro doses de $\mathrm{N}\left(0 \mathrm{~kg} \mathrm{ha}^{-1}, 20 \mathrm{~kg} \mathrm{ha}^{-1}, 40 \mathrm{~kg} \mathrm{ha}^{-1}\right.$ e $\left.60 \mathrm{~kg} \mathrm{ha}^{-1}\right)$. Avaliaram-se a altura de planta, matéria seca da parte aérea, número e matéria seca de nódulos, altura de inserção da primeira vagem, número de vagens e de grãos por vagem, massa de mil grãos, produtividade de grãos e índice de colheita. A adubação não resultou em aumento nos componentes de produção e produtividade de grãos, independentemente das doses e épocas de aplicação. Por isso, concluise que, se estirpes eficientes de B. japonicum forem utilizadas em áreas de primeiro cultivo de soja em Neossolo Quartzarênico de média a alta fertilidade, em especial com disponibilidade relativamente alta de $\mathrm{N}$ devido à mineralização de matéria orgânica do solo, não há necessidade de se aplicar doses iniciais ou tardias de adubação nitrogenada.

PALAVRAS-CHAVE: Glycine max L. Merrill; fixação biológica de nitrogênio; ureia; nodulação.

the growing season and has an especially high nitrogen $(\mathrm{N})$ requirement due to its seed protein content. According to Kaschuk et al. (2016), around $80 \mathrm{~kg}$ of $\mathrm{N}$ are used for each ton of seed-soybean produced. Soybean $\mathrm{N}$ requirements have a peak during the growth stages of pod development and grain filling (Kaschuk et al. 2010, Hungria \& Mendes

1. Received: Apr. 23, 2018. Accepted: Jul. 03, 2018. Published: Dec. 10, 2018. DOI: 10.1590/1983-40632018v4852637.

2. Universidade Federal de Mato Grosso do Sul, Departamento de Agronomia, Chapadão do Sul, MS, Brasil. E-mail/ORCID: alan_zuffo@hotmail.com/0000-0001-9704-5325.

3. Universidade Estadual de Mato Grosso do Sul, Departamento de Agronomia, Cassilândia, MS, Brasil. E-mail/ORCID: steiner@uems.br/0000-0001-9091-1737, busch088@gmail.com/0000-0002-7843-9158, zoz@uems.br/0000-0003-2991-5485. 
2015) and are generally fulfilled by biological $\mathrm{N}$ fixation through the symbiosis with Bradyrhizobium japonicum and Bradyrhizobium elkani (Domingos et al. 2015), plus $\mathrm{N}$ uptake from the soil.

The use of early soybean cultivars with indeterminate growth has increased in recent years, in Brazil. The characteristics of these cultivars allow the cultivation of two crops per agricultural year, when farmers grow mainly soybean/corn or soybean/ cotton. Studies with the use of $\mathrm{N}$ fertilizer in soybean cultivation have shown inconsistent responses, in terms of nodulation and grain yield, which may be due to differences in soybean cultivars. However, responses of high potential early cultivars to the $\mathrm{N}$ application are unknown.

Recent research results have shown that the application of $\mathrm{N}$ fertilizers does not improve the crop grain yield (Aratani et al. 2008, Kaschuk et al. 2016, Korber et al. 2017). In contrast, other research studies have shown that the $\mathrm{N}$ application can improve the plant growth and crop grain yield (Parente et al. 2015, Barranqueiro \& Dalchiavon 2017, Moreno et al. 2018). The current recommendation for soybean cultivation in Brazil is the use of inoculant containing Bradyrhizobium strains without the addition of $\mathrm{N}$ fertilizer, or up to the rate of $20 \mathrm{~kg} \mathrm{ha}^{-1}$ of $\mathrm{N}$ at sowing, when the soil is low in organic matter (Embrapa 2011).

The impacts of the use of chemical $\mathrm{N}$ fertilizer on the $\mathrm{N}$ fixation and crop yield depend on the soybean cultivars and Bradyrhizobium strain, as well as on the amount and time of $\mathrm{N}$ application. McCoy et al. (2018) verified that $\mathrm{N}$ application rates at sowing resulted in inhibition of root nodulation and root growth of soybean plants. Kaschuk et al. (2016), evaluating the effect of $\mathrm{N}$ application rates $\left(30 \mathrm{~kg} \mathrm{ha}^{-1}\right.$ and $\left.50 \mathrm{~kg} \mathrm{ha}^{-1}\right)$ at sowing or full flowering of the soybean crop, found that the $\mathrm{N}$ fertilizer negatively affected the nodule number and size, pointing out a down-regulation in the symbiotic performance, without improving crop yields. Korber et al. (2017) observed that application rates of $20-80 \mathrm{~kg} \mathrm{ha}^{-1}$ of $\mathrm{N}$ at 30 days after the emergence (V6 stage) do not affect the soybean crop yield. On the other hand, Moreno et al. (2018) reported that the split application of $40 \mathrm{~kg} \mathrm{ha}^{-1}$ of $\mathrm{N}$ [at sowing and pod development ( $\mathrm{R} 4$ stage)] provides an increase in the crop grain yield, if compared to the non-fertilized treatment with $\mathrm{N}$. Therefore, new studies should be carried out to evaluate the soybean yield response to the $\mathrm{N}$ fertilizer application and if this technique is economically sustainable, as well as to define the rate and the appropriate time of application.

With the increased planting of new soybean cultivars with early cycle and high $\mathrm{N}$ demand to sustain current grain yield indices, a new issue has been reported in the agronomic research. Would these cultivars need basal and/or topdressing $\mathrm{N}$ application, as perhaps symbiotic $\mathrm{N}_{2}$ fixation would not catch up with the increased $\mathrm{N}$ needs? (Kaschuk et al. 2016). This study aimed to evaluate the response of early soybean cultivars to doses and times of $\mathrm{N}$ fertilizer application, associated with inoculation of Bradyrhizobium japonicum.

\section{MATERIAL AND METHODS}

Two field experiments were conducted in a deep sandy soil, classified as Neossolo Quartzarênico Órtico latossólico - RQo (Santos et al. 2013) or simply Quartzipsamment (USDA 2014), with 84-86 \% of sand, in Cassilândia, Mato Grosso do Sul state, Brazil (1906'48' S, 51 $44^{\circ} 03^{\prime}$ 'W and altitude of $510 \mathrm{~m}$ ), during the 2016/2017 and $2017 / 2018$ growing seasons. The occurrence of Quartzipsamments in the eastern region of the Mato Grosso do Sul state is common, and this class of soil has no restrictions for use and management (Santos et al. 2013).

The regional climate, according to the Köppen classification, is Aw, characterized as tropical, with hot summers and a tendency toward high rainfall levels, and dry winters, with a dry season between May and September. The mean annual temperature is $24.1^{\circ} \mathrm{C}$, with a minimum of $16.4{ }^{\circ} \mathrm{C}$ (July) and a maximum of $28.6^{\circ} \mathrm{C}$ (January), with a mean annual rainfall of $1,520 \mathrm{~mm}$. The rainfall data gathered during the experiments are shown in Figure 1. The total rainfall, during the 2016/2017 growing season, was $1,032 \mathrm{~mm}$, while, in the $2017 / 2018$ growing season, it was $676 \mathrm{~mm}$.

Before conducting these experiments, the area had no known history of Bradyrhizobium inoculation and was occupied by Urochloa sp. pasture, without any fertilization, for twelve years. First cultivation areas of soybean are considered ideal for testing the interaction between Bradyrhizobium-soybean symbiosis and $\mathrm{N}$ fertilizer application. The field soil was plowed and harrowed to a depth of $0.25 \mathrm{~m}$ and divided into plots before sowing. Before starting the 
experiments, the soil was sampled at the $0-0.20 \mathrm{~m}$ layer, and the results of the chemical analysis are shown in Table 1.

The experiments were arranged in a complete randomized block design, in a $2 \times 3 \times 4$ factorial scheme, with four replicates. Treatments consisted of two soybean cultivars (BRS 1074 IPRO indeterminate growth type, cycle of 108-115 days, maturation group 7.4; and ST 797 IPRO - indeterminate growth type, cycle of 110-125 days, maturity group 7.9); three $\mathrm{N}$ fertilizer application times (at sowing, 30 and 50 days after the emergence - DAE); and four $\mathrm{N}$ doses $\left(0 \mathrm{~kg} \mathrm{ha}^{-1}, 20 \mathrm{~kg} \mathrm{ha}^{-1}, 40 \mathrm{~kg} \mathrm{ha}^{-1}\right.$ and $\left.60 \mathrm{~kg} \mathrm{ha}^{-1}\right)$. The $\mathrm{N}$ fertilizer used was urea ( $45 \%$ of $\mathrm{N})$. The experimental units consisted of eight $5.0-\mathrm{m}$ long rows, with $0.50 \mathrm{~m}$ between rows. The useful area comprised the four central rows of each plot, disregarding $0.50 \mathrm{~m}$ of each edge.

The soybean seeds were sown manually on December 15, 2016 (2016/2017 growing season) and December 08, 2017 (2017/2018 growing season), in rows of $0.50 \mathrm{~m}$ apart, at a density of

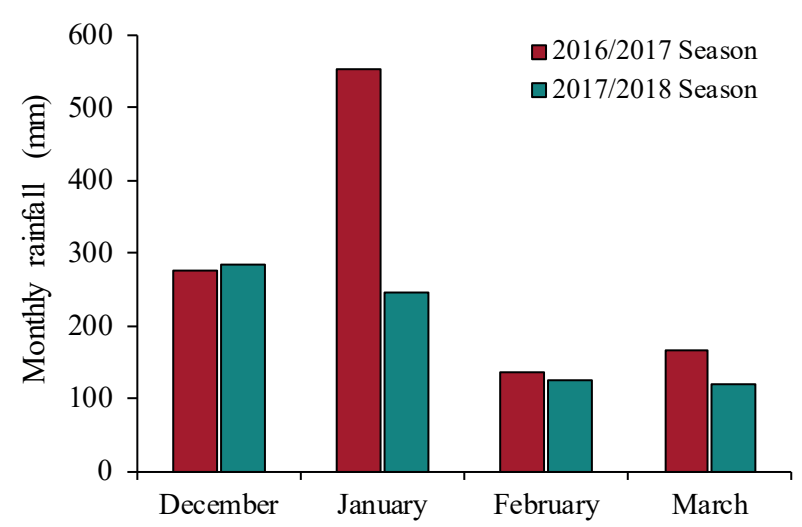

Figure 1. Monthly rainfall during two growing seasons (2016/2017 and 2017/2018) of soybean in Cassilândia, Mato Grosso do Sul state, Brazil.
15 seeds $\mathrm{m}^{-1}$. Phosphorus and potassium fertilization were carried out by applying $120 \mathrm{~kg} \mathrm{ha}^{-1}$ of $\mathrm{P}_{2} \mathrm{O}_{5}$ (simple superphosphate) and $45 \mathrm{~kg} \mathrm{ha}^{-1}$ of $\mathrm{K}_{2} \mathrm{O}$ (potassium chloride) at sowing, and $45 \mathrm{~kg} \mathrm{ha}^{-1}$ of $\mathrm{K}_{2} \mathrm{O}$ as topdressing (potassium chloride), at 30 DAE. The soybean fertilization was carried out according to the crop requirements (Embrapa 2011) and the soil analysis (Table 1).

All soybean seeds used in the experiments were previously treated with pyraclostrobin + methyl thiophanate + fipronil $\left(\right.$ Standak Top $\left.{ }^{\circledR}\right)$ at the rate of $2 \mathrm{~mL}$ c.p. $\mathrm{kg}^{-1}$ of seed and then inoculated with efficient Bradyrhizobium japonicum strains. The commercial liquid inoculant Simbiose Nod Soja ${ }^{\circledR}$ (Simbiose: Biological Agrotechnology), containing SEMIA 5079 and SEMIA 5080 strains (minimum concentration of $7.2 \times 10^{9}$ viable cells per $\mathrm{mL}$ ) at a rate of $3.0 \mathrm{~mL} \mathrm{~kg}^{-1}$ of seeds, was used. The amount of inoculant used was added to a solution containing $2.0 \mathrm{~mL} \mathrm{~kg}^{-1}$ of additive for inoculant Protege ${ }^{\circledR}$ TS (Total Biotechnology), and then both products (inoculant + additive) were applied to the seeds. The inoculant additive consists of active metabolites of bacteria, sugar complex and encapsulating biopolymers, and has the purpose of improving the protection and viability of the bacteria on the seeds. To potentiate the soybean nodulation, the seeds were also subjected to an application of micronutrients, especially molybdenum. The commercial seed fertilizer Nódulus ${ }^{\circledR}$ Premium 125 (Biosoja), containing $10 \%$ of Mo, $1 \%$ of Co, $1 \%$ of $\mathrm{S}, 1 \%$ of $\mathrm{Ca}$ and $0.2 \%$ of $\mathrm{Fe}$, was used. In this study, all treatments were inoculated with elite strains of Bradyrhizobium japonicum, since it is a wellestablished and effective practice for the soybean production in tropical areas (Embrapa 2011).

During the plant development, the management of weeds, pests and diseases was carried out according to the requirements of the crop and

Table 1. Soil chemical properties ${ }^{1}(0.0-0.20 \mathrm{~m}$ depth) at the beginning of the experiments.

\begin{tabular}{|c|c|c|c|c|c|c|c|c|c|c|}
\hline \multirow{2}{*}{ Growing season } & $\mathrm{pH}$ & $\mathrm{OM}$ & $\mathrm{P}_{\text {Mehlich-1 }}$ & $\mathrm{H}+\mathrm{Al}$ & $\mathrm{Al}^{3+}$ & $\mathrm{Ca}^{2+}$ & $\mathrm{Mg}^{2+}$ & $\mathrm{K}^{+}$ & $\mathrm{CEC}$ & \multirow{2}{*}{$\frac{\mathrm{V}}{\%}$} \\
\hline & $\mathrm{CaCl}_{2}$ & $\mathrm{~g} \mathrm{~kg}^{-1}$ & $\mathrm{mg} \mathrm{dm} \mathrm{m}^{-3}$ & \multicolumn{6}{|c|}{$\mathrm{cmol}_{\mathrm{c}} \mathrm{dm}^{-3}$} & \\
\hline $2016 / 2017$ & 5.6 & 14.0 & 8.30 & 2.00 & 0.00 & 2.00 & 0.70 & 0.07 & 4.77 & 58 \\
\hline $2017 / 2018$ & 5.2 & 16.4 & 10.70 & 2.30 & 0.00 & 2.10 & 0.80 & 0.12 & 5.32 & 56 \\
\hline \multirow{2}{*}{ Growing season } & $\mathrm{S}-\mathrm{SO}_{4}$ & $\mathrm{~B}$ & \multicolumn{2}{|c|}{$\mathrm{Cu}$} & & n & \multicolumn{2}{|c|}{$\mathrm{Fe}$} & \multicolumn{2}{|c|}{$\mathrm{Mn}$} \\
\hline & 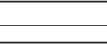 & & & & $\mathrm{ng} \mathrm{d}$ & & & & & \\
\hline $2016 / 2017$ & 1.82 & 0.45 & \multicolumn{2}{|c|}{0.90} & & 26 & \multicolumn{2}{|c|}{32.0} & \multicolumn{2}{|c|}{76.8} \\
\hline $2017 / 2018$ & 1.13 & 0.38 & \multicolumn{2}{|c|}{1.12} & & 64 & \multicolumn{2}{|c|}{27.1} & \multicolumn{2}{|c|}{55.1} \\
\hline
\end{tabular}


technical recommendations (Embrapa 2011). The following products were used: glyphosate, pyraclostrobin + epoxiconazole, azoxystrobin + cyproconazole, teflubenzurom, chlorpyrifos and cypermethrin.

The nodulation and dry matter accumulation of soybean plants were assessed at the beginning of the pod development (R3 stage). Five plants of each plot were cut at the soil surface, and then roots were carefully dug out and collected into polythene bags, together with detached nodules, and transported to the laboratory. The roots were put in a $1-\mathrm{mm}$ mesh sieve and washed under running tap water to remove the adhered soil. The nodules were carefully removed, washed and counted. Plant height $(\mathrm{cm})$ was determined from the soil surface to the apical meristem of the plant with a millimeter ruler. Shoot and nodules were oven dried at $65^{\circ} \mathrm{C}$, for $72 \mathrm{~h}$, and then weighed.

At full maturity (R8 stage), the first pod height, grain yield and production components (number of pods, number of grains per pod, 1,000-grain mass and grain harvest index) were evaluated. The first pod height $(\mathrm{cm})$ was determined from the soil surface to the insertion of the first pod, with a millimeter ruler. Grain yield was determined at the end of the crop cycle, from a central portion of each subplot of $4.0 \mathrm{~m} \times 1.0 \mathrm{~m}\left(4.0 \mathrm{~m}^{2}\right)$. Grains were cleaned and weighed, and the grain yield was estimated after the correction of grain weights to $13 \%$ of moisture. The average number of pods per plant and average number of grains per pod were determined in a random sample of five plants in the useful area of the plot, and the mass of 1,000 grains by the average of three measurements of 100 grains taken at random. The grain harvest index was obtained by the quotient between the grain yield and total shoot dry matter yield (grains + plant shoot residues).

The data normality was previously tested by the Kolmogorov-Smirnov test at the $5 \%$ significance level, and then the data were submitted to analysis of variance (Anova). When significant, the means were compared by the least significant differences test at the $5 \%$ probability level. Regression analysis was used for the $\mathrm{N}$ fertilizer levels, and significant equations (F-test; p $\leq 0.05$ ) with the highest coefficients of determination were adjusted. For the statistical analysis, the data for number of nodules and nodule dry matter were previously transformed into $(\mathrm{x}+0.5)^{0.5}$. All analyses were performed using the Sisvar ${ }^{\circledR}$ software (Ferreira 2011).

\section{RESULTS AND DISCUSSION}

The results of the analysis of variance did not show significant effects $(p>0.05)$ for the interaction among the tested factors (cultivar, rates and times of $\mathrm{N}$ fertilizer application) for any of the traits measured (Table 2). Therefore, the results are presented separately for the main effects of these factors. The absence of significant interaction among the studied factors indicates that the soybean cultivars have a similar response to the different rates and times of $\mathrm{N}$ fertilizer application.

The results showed significant effects among the soybean cultivars for the number of nodules in the 2016/2017 growing season, and number and dry matter of the nodules in the $2017 / 2018$ one (Table 3 ). It indicates that the two soybean cultivars have different nodulation potentials, with ST 797 IPRO presenting a higher root nodulation capacity in both growing seasons, if compared to BRS 1074 IPRO (Table 3). The distinct nodulation potential (number and dry matter of nodules) among Brazilian soybean cultivars has been commonly reported in other studies (Zuffo et al. 2014, Parente et al. 2015, Cerezini et al. 2017). These variations in the root nodulation capacity are related to differences in the genetic potential and other intrinsic characteristics of each cultivar (Felisberto et al. 2015, Soares et al. 2015).

The plant height and shoot dry matter were similar between the two soybean cultivars, in both growing seasons (Table 3). These results may be due to the fact that the height and shoot dry matter accumulation of the plants are two agronomic traits controlled mainly by genetic factors of the cultivar, and that the two cultivars used in this study have a similar shoot growth potential. Parente et al. (2015) also reported the similarity of plant height in two other soybean cultivars with high productive potential (BMX Potência RR and BRS Valiosa RR).

The $\mathrm{N}$ fertilizer application times significantly affected $(p<0.05)$ only the number and dry matter of nodules of the soybean plants in the 2016/2017 growing season (Table 3 ). The number and dry matter of nodules per plant were significantly higher when the $\mathrm{N}$ fertilizer was applied at sowing, followed by applications at $50 \mathrm{DAE}$, and lower with applications at 30 DAE (Table 3). These results indicate that the $\mathrm{N}$ fertilizer application at $30 \mathrm{DAE}$ inhibited the formation of the soybean root nodules. However, this effect on nodulation inhibition was not reported 
for the application of $\mathrm{N}$ fertilizer at sowing, what could be related to the non-synchronism between the beginning of the nodulation stimulus and the higher soil N availability, as reported by Saito et al. (2014).
The inhibition of the nodulation process in soybean plants with the use of $\mathrm{N}$ fertilizer has been reported in other studies. Kaschuk et al. (2016) found that the application of $30 \mathrm{~kg} \mathrm{ha}^{-1}$ and $50 \mathrm{~kg} \mathrm{ha}^{-1}$ of $\mathrm{N}$ at

Table 2. F-test probability values of the analysis of variance for agronomic traits associated with nodulation, dry matter, grain yield and production components of the soybean crop, as affected by the factors cultivar, rates and times of $\mathrm{N}$ fertilizer application, during two growing seasons (2017/2017 and 2017/2018).

\begin{tabular}{|c|c|c|c|c|c|c|c|c|c|c|}
\hline \multirow{2}{*}{ Source of variation } & \multicolumn{10}{|c|}{ Trait $^{1}$} \\
\hline & $\mathrm{PH}$ & SDM & $\mathrm{NN}$ & NDM & FPH & NPP & NGP & $1,000-\mathrm{G}$ & GY & GHI \\
\hline & \multicolumn{10}{|c|}{-2016/2017 growing season } \\
\hline Cultivar (C) & 0.291 & 0.247 & 0.010 & 0.317 & 0.808 & $<0.010$ & 0.047 & 0.210 & 0.070 & 0.192 \\
\hline Application time $(\mathrm{T})$ & 0.433 & 0.434 & 0.025 & 0.016 & 0.878 & 0.096 & 0.565 & 0.127 & 0.299 & 0.118 \\
\hline Nitrogen rate $(\mathrm{N})$ & 0.016 & $<0.010$ & 0.420 & 0.087 & 0.372 & 0.615 & 0.972 & 0.439 & 0.534 & 0.388 \\
\hline $\mathrm{C} \times \mathrm{T}$ & 0.441 & 0.292 & 0.474 & 0.245 & 0.156 & 0.315 & 0.726 & 0.843 & 0.162 & 0.803 \\
\hline $\mathrm{C} \times \mathrm{N}$ & 0.370 & 0.522 & 0.905 & 0.266 & 0.681 & 0.250 & 0.592 & 0.100 & 0.405 & 0.852 \\
\hline $\mathrm{T} \times \mathrm{N}$ & 0.799 & 0.434 & 0.996 & 0.676 & 0.778 & 0.347 & 0.266 & 0.344 & 0.657 & 0.700 \\
\hline $\mathrm{C} \times \mathrm{T} \times \mathrm{N}$ & 0.440 & 0.212 & 0.727 & 0.181 & 0.946 & 0.945 & 0.583 & 0.138 & 0.958 & 0.650 \\
\hline \multirow[t]{2}{*}{ CV (\%) } & 8.540 & 22.070 & 30.810 & 8.060 & 11.070 & 14.470 & 11.390 & 5.630 & 6.220 & 6.860 \\
\hline & \multicolumn{10}{|c|}{-2017/2018 growing season } \\
\hline Cultivar (C) & 0.097 & 0.976 & 0.041 & 0.017 & 0.209 & 0.196 & 0.918 & $<0.010$ & $<0.010$ & $<0.010$ \\
\hline Application time $(\mathrm{T})$ & 0.703 & 0.489 & 0.268 & 0.213 & 0.335 & 0.935 & 0.924 & 0.288 & 0.259 & 0.322 \\
\hline Nitrogen rate $(\mathrm{N})$ & 0.483 & 0.027 & 0.926 & 0.517 & 0.143 & 0.455 & 0.178 & 0.026 & 0.721 & 0.245 \\
\hline $\mathrm{C} \times \mathrm{T}$ & 0.498 & 0.433 & 0.254 & 0.061 & 0.504 & 0.608 & 0.301 & 0.203 & 0.825 & 0.299 \\
\hline $\mathrm{C} \times \mathrm{N}$ & 0.433 & 0.612 & 0.894 & 0.770 & 0.367 & 0.929 & 0.169 & 0.501 & 0.427 & 0.110 \\
\hline $\mathrm{T} \times \mathrm{N}$ & 0.073 & 0.272 & 0.531 & 0.416 & 0.284 & 0.961 & 0.211 & 0.195 & 0.747 & 0.333 \\
\hline $\mathrm{C} \times \mathrm{T} \times \mathrm{N}$ & 0.847 & 0.117 & 0.739 & 0.265 & 0.936 & 0.902 & 0.477 & 0.344 & 0.844 & 0.140 \\
\hline CV (\%) & 12.670 & 17.270 & 26.820 & 21.520 & 13.580 & 15.000 & 17.920 & 14.510 & 16.110 & 10.350 \\
\hline
\end{tabular}

Table 3. Means for plant height, shoot dry matter, number and dry matter of nodules, as a result of nitrogen application times and soybean cultivars [Glycine max (L.) Merrill.], in the 2016/2017 and 2017/2018 growing seasons.

\begin{tabular}{|c|c|c|c|c|}
\hline \multirow{2}{*}{ Factor/treatment } & Plant height & Shoot dry matter & Number of nodules & Nodule dry matter \\
\hline & $\mathrm{cm}$ & g plant $^{-1}$ & unit plant $^{-1}$ & g plant $^{-1}$ \\
\hline & & -2016 & growing season- & \\
\hline \multicolumn{5}{|l|}{ Cultivar ${ }^{1}$} \\
\hline BRS 1074 IPRO & $51.22 \mathrm{a}$ & $18.50 \mathrm{a}$ & $14.36 \mathrm{~b}$ & $490 \mathrm{a}$ \\
\hline ST 797 IPRO & $52.33 \mathrm{a}$ & $17.41 \mathrm{a}$ & $20.21 \mathrm{a}$ & $550 \mathrm{a}$ \\
\hline \multicolumn{5}{|l|}{ Nitrogen application time ${ }^{2}$} \\
\hline Sowing & $50.93 \mathrm{a}$ & $18.78 \mathrm{a}$ & $22.52 \mathrm{a}$ & $590 \mathrm{a}$ \\
\hline $30 \mathrm{DAE}^{3}$ & $51.80 \mathrm{a}$ & $17.32 \mathrm{a}$ & $12.97 \mathrm{~b}$ & $390 \mathrm{~b}$ \\
\hline $50 \mathrm{DAE}$ & $52.59 \mathrm{a}$ & $17.77 \mathrm{a}$ & $16.36 \mathrm{ab}$ & $570 \mathrm{a}$ \\
\hline & & 2017 & growing season & 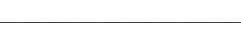 \\
\hline \multicolumn{5}{|l|}{ Cultivar ${ }^{1}$} \\
\hline BRS 1074 IPRO & $52.64 \mathrm{a}$ & $21.92 \mathrm{a}$ & $1.24 \mathrm{~b}$ & $26.66 \mathrm{~b}$ \\
\hline ST 797 IPRO & $55.37 \mathrm{a}$ & $21.98 \mathrm{a}$ & $1.69 \mathrm{a}$ & $64.98 \mathrm{a}$ \\
\hline \multicolumn{5}{|l|}{ Nitrogen application time ${ }^{2}$} \\
\hline Sowing & $53.23 \mathrm{a}$ & $20.96 \mathrm{a}$ & $1.25 \mathrm{a}$ & $23.42 \mathrm{a}$ \\
\hline $30 \mathrm{DAE}$ & $54.89 \mathrm{a}$ & $23.61 \mathrm{a}$ & $1.69 \mathrm{a}$ & $64.42 \mathrm{a}$ \\
\hline $50 \mathrm{DAE}$ & $53.90 \mathrm{a}$ & $21.27 \mathrm{a}$ & $1.46 \mathrm{a}$ & $49.62 \mathrm{a}$ \\
\hline
\end{tabular}


full flowering negatively affects the number and dry matter of nodules. McCoy et al. (2018) verified that the $\mathrm{N}$ fertilizer application results in the inhibition of the root nodulation of soybean plants. Parente et al. (2015) observed that the application of $\mathrm{N}$ fertilizer at sowing results in a reduction in the number and dry matter of the nodules. According to Embrapa (2011), the application of $\mathrm{N}$ fertilizer at sowing or as topdressing, in any development stage of the soybean crop, reduces the nodulation and efficiency of the biological nitrogen fixation.

Negative effects of the $\mathrm{N}$ fertilizer application on the nodule formation in soybean plants are due to the effect of this nutrient on the different stages of the nodulation process. The stimulus to initiate the nodule formation is dependent on the $\mathrm{N}$ concentration of the soil, and the increased $\mathrm{N}$ availability in the soil solution results in the inhibition of nodule formation and growth (Saito et al. 2014). However, these results are contrary to those reported by Aratani et al. (2008), who verified that, regardless of the application time, the $\mathrm{N}$ fertilization does not interfere in the soybean root nodulation. These results were also observed in this study for the 2017/2018 season, when the use of
$\mathrm{N}$ fertilizer in the soybean crop did not negatively affect the number and dry matter of nodules (Table 3).

The effectiveness of the soybean nodulation process can be verified when there are 10-30 nodules per plant (Embrapa 2011). The lower number of root nodules found in the $2017 / 2018$ growing season (Table 3) may be related to the lower rainfall rate observed in this agricultural year (Figure 1). Parente et al. (2015) also reported a low number of root nodules in soybean cultivars under low rainfall conditions and with prolonged drought periods during the early stages of crop development. The survival of the soil bacterial community is dependent on several factors, such as soil $\mathrm{pH}$, nutrient concentration, salinity and soil water content. The microorganism population of the soil is reduced with the decrease of the rainfall rate and, therefore, a low soil moisture can inhibit the root nodule formation and adversely affect the nodulation process of plants (Cerezini et al. 2017).

The different $\mathrm{N}$ doses applied significantly affected $(p<0.05)$ the plant height in the 2016/2017 growing season (Figure $2 \mathrm{a}$ ), as well as the shoot dry matter in both growing seasons (Figure $2 b$ ). However, the number and dry matter of nodules in both growing
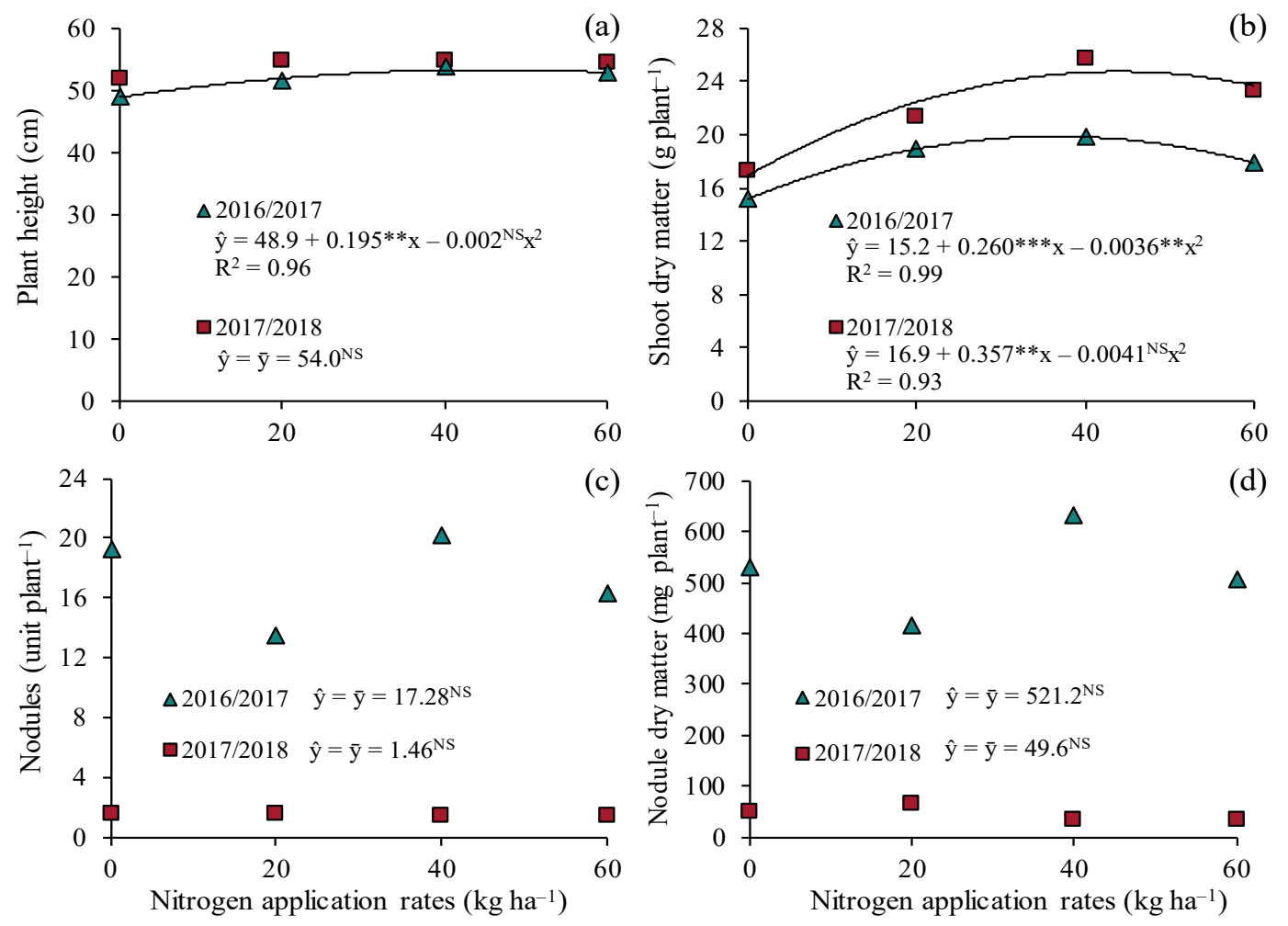

Figure 2. Effects of application rates of $\mathrm{N}$ fertilizer on plant height (a), shoot dry matter (b), number of nodules per plant (c) and nodule dry matter (d) of soybean cultivars [Glycine max (L.) Merrill.], in the 2016/2017 and 2017/2018 growing seasons. 
seasons were not significantly affected $(p>0.05)$ by the $\mathrm{N}$ fertilizer rates (Figures $2 \mathrm{c}$ and $2 \mathrm{~d}$ ). The highest plant height in the 2016/2017 season $(53.7 \mathrm{~cm}$ ) was obtained with the application of $49 \mathrm{~kg} \mathrm{ha}^{-1}$ of $\mathrm{N}$, whereas, in the 2017/2018 season, the plant height remained constant in all the $\mathrm{N}$ levels assessed (Figure 2a). In the 2016/2017 growing season, the highest accumulation for shoot dry matter (19.9 g plant $\left.{ }^{-1}\right)$ was obtained with the application of $36 \mathrm{~kg} \mathrm{ha}^{-1}$ of $\mathrm{N}$, whereas the highest accumulation for shoot dry matter $\left(24.7 \mathrm{~g} \mathrm{plant}^{-1}\right)$ in the $2017 / 2018$ season was obtained with the application of $44 \mathrm{~kg} \mathrm{ha}^{-1}$ of N (Figure $2 \mathrm{~b}$ ). In general, these results show that the optimal $\mathrm{N}$ application rate for soybean shoot growth may range between $35 \mathrm{~kg} \mathrm{ha}^{-1}$ and
$50 \mathrm{~kg} \mathrm{ha}^{-1}$ of N. Similarly, Parente et al. (2015) also found a positive response to $\mathrm{N}$ fertilizer applications up to $40 \mathrm{~kg} \mathrm{ha}^{-1}$ of $\mathrm{N}$ in the shoot growth of soybean plants. These results are due to $\mathrm{N}$ being one of the most important nutrients to increase the growth and dry matter production of plants, because it is a constituent of amino acids, proteins, enzymes and the chlorophyll molecule, with a marked effect on the increase of the photosynthetic rate (Taiz et al. 2017). However, this improvement in the shoot growth of soybean plants did not increase the production components and grain yield of the crop (Figure 3).

The soybean nodulation (number and dry matter) was not influenced by the increase of
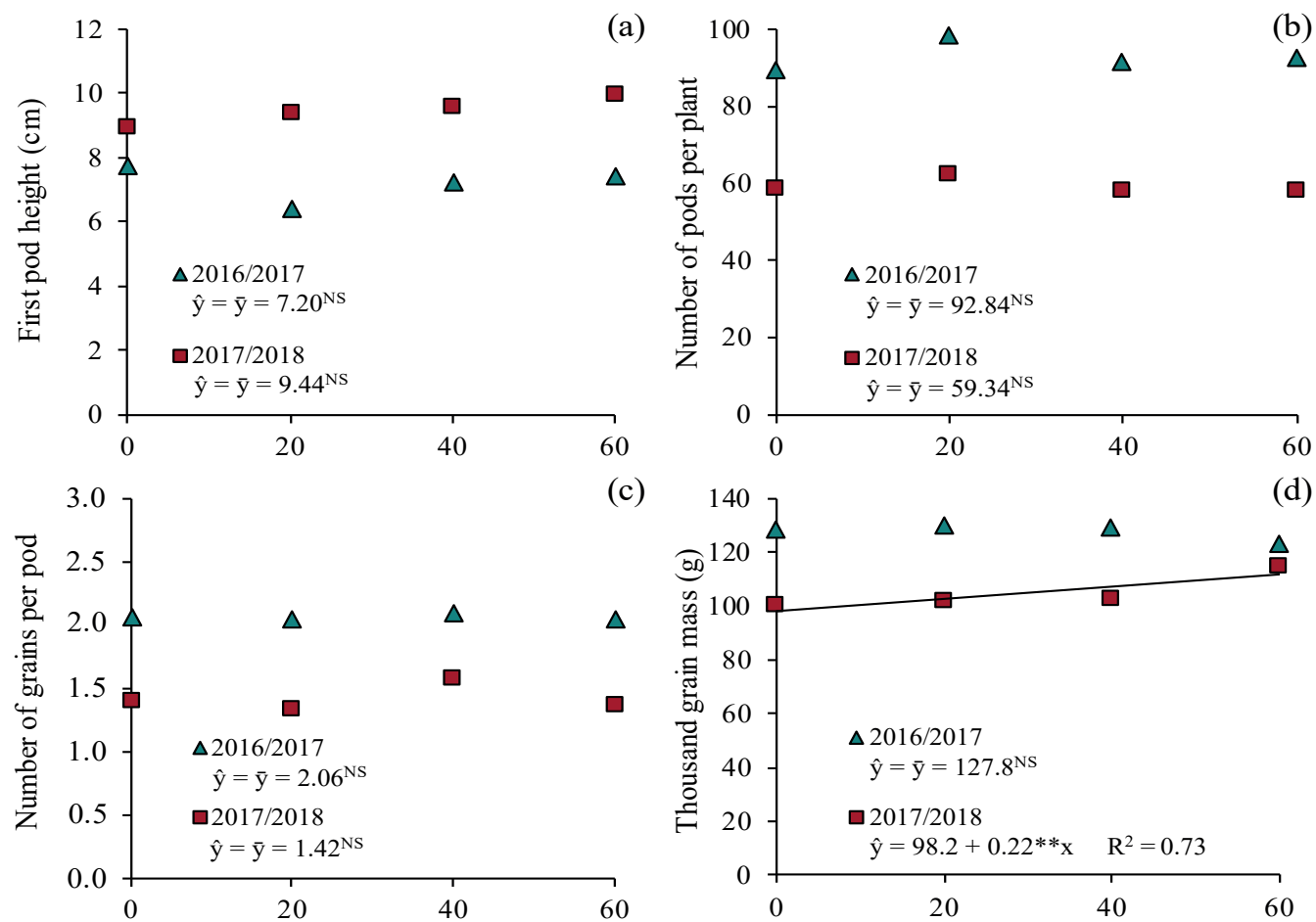

c)
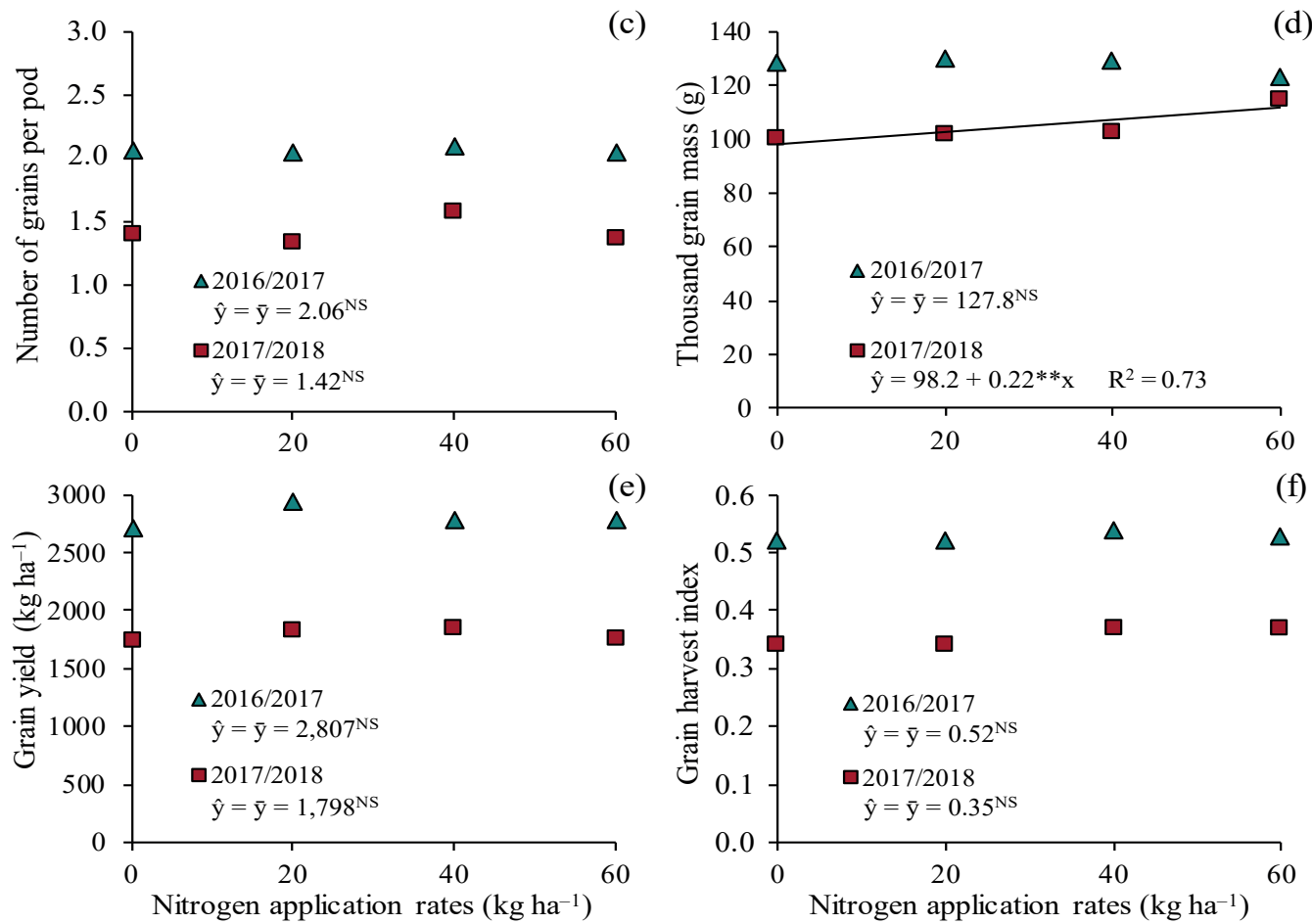

Figure 3. Effects of the $\mathrm{N}$ fertilizer application rates on first pod height (a), number of pods per plant (b), number of grains per pod (c), 1,000-grain mass (d), grain yield (e) and grain harvest index (f) of soybean cultivars [Glycine max (L.) Merrill.], in the 2016/2017 and 2017/2018 growing seasons. 
fertilizer rates up to $60 \mathrm{~kg} \mathrm{ha}^{-1}$, in both growing seasons (Figures 2c and 2d). Similarly, Aratani et al. (2008) also verified that the application of $90 \mathrm{~kg} \mathrm{ha}^{-1}$ of $\mathrm{N}$ resulted in a number and dry matter of soybean nodules equivalent to the unfertilized treatment with N. Mendes et al. (2008) found that the fertilizer application of up to $50 \mathrm{~kg} \mathrm{ha}^{-1}$ of $\mathrm{N}$ did not interfere with the dry matter of the nodules, whereas, with the application of $200 \mathrm{~kg} \mathrm{ha}^{-1}$ of $\mathrm{N}$, the soybean nodulation was severely inhibited. According to Giller \& Wilson (1991), the rate of N application required to cause nodulation suppression varies with species, cultivars and application time, and the addition of this nutrient has a more marked effect on nodule size, when compared to the number of nodules per plant. In this study, fertilizer rates of up to $60 \mathrm{~kg} \mathrm{ha}^{-1}$ of $\mathrm{N}$ did not inhibit the soybean nodulation (Figures $2 \mathrm{c}$ and $2 \mathrm{~d}$ ). However, the $\mathrm{N}$ application at $30 \mathrm{DAE}$ resulted in lower number and dry matter of the nodules, in the 2016/2017 growing season (Table 3 ). In general, negative effects of the $\mathrm{N}$ fertilizer application on the formation of soybean nodules have generally been reported in other studies, due to the interaction of this nutrient with the stimulus to initiate the nodule formation (Saito et al. 2014).

In the 2016/2017 growing season, there was a significant difference $(p<0.05)$ between the soybean cultivars for the number of pods per plant and number of grains per pod, with the highest means for the ST 797 IPRO cultivar (Table 4). In the 2017/2018 season, the highest 1,000-grain mass, grain yield and grain harvest index were obtained for the BRS 1074 IPRO cultivar, whereas other agronomic traits did not show differences between the cultivars (Table 4). Parente et al. (2015), evaluating the effect of $\mathrm{N}$ fertilization on two other soybean cultivars, also reported genotypic differences for 1,000-grain mass and grain yield. These soybean cultivar differences for the production components and grain yield may be related to the genetic potential and other intrinsic characteristics of each cultivar (Felisberto et al. 2015, Soares et al. 2015).

The highest grain yield obtained with the BRS 1074 IPRO cultivar in the 2017/2018 growing season may be due to the greater adaptability and yield stability of this cultivar to the different production environments, when compared to the ST 797 IPRO cultivar. Thus, the lower rainfall rate during the 2017/2018 growing season (Figure 1) resulted in a lower yield decrease for the BRS 1074 IPRO cultivar, if compared to the ST 797 IPRO, which is a responsive cultivar, with a higher yield potential in unrestricted environments. Under conditions of higher rainfall rate, as in the 2016/2017 season, these

Table 4. Means for the first pod height, number of pods per plant, number of grains per pod, 1,000-grain mass, grain yield and grain harvest index, as a result of $\mathrm{N}$ application times and soybean cultivars [Glycine max (L.) Merrill.], in the 2016/2017 and 2017/2018 growing seasons.

\begin{tabular}{|c|c|c|c|c|c|c|}
\hline \multirow[t]{2}{*}{ Factor/treatment } & $\begin{array}{l}\text { First pod } \\
\text { height }\end{array}$ & $\begin{array}{l}\text { Number of } \\
\text { pods }\end{array}$ & $\begin{array}{l}\text { Number of grains } \\
\text { per pod }\end{array}$ & $\begin{array}{c}1,000 \text {-grain } \\
\text { mass }\end{array}$ & $\begin{array}{l}\text { Grain } \\
\text { yield }\end{array}$ & \multirow{2}{*}{$\begin{array}{c}\text { Harvest } \\
\text { index }\end{array}$} \\
\hline & $\mathrm{cm}$ & unit & unit & $\mathrm{g}$ & $\mathrm{kg} \mathrm{ha}^{-1}$ & \\
\hline & & & 2016/2017 grow & season- & & 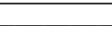 \\
\hline \multicolumn{7}{|l|}{ Cultivar $^{1}$} \\
\hline BRS 1074 IPRO & $7.68 \mathrm{a}$ & $90.0 \mathrm{~b}$ & $1.98 \mathrm{~b}$ & $130.1 \mathrm{a}$ & $2,793 \mathrm{a}$ & $0.52 \mathrm{a}$ \\
\hline ST 797 IPRO & $7.11 \mathrm{a}$ & $96.8 \mathrm{a}$ & $2.13 \mathrm{a}$ & $125.5 \mathrm{a}$ & $2,720 \mathrm{a}$ & $0.53 \mathrm{a}$ \\
\hline \multicolumn{7}{|c|}{ Nitrogen application time ${ }^{2}$} \\
\hline Sowing & $7.35 \mathrm{a}$ & $85.1 \mathrm{a}$ & $2.04 \mathrm{a}$ & $127.5 \mathrm{a}$ & $2,788 \mathrm{a}$ & $0.53 \mathrm{a}$ \\
\hline $30 \mathrm{DAE}^{3}$ & $7.10 \mathrm{a}$ & $97.3 \mathrm{a}$ & $2.03 \mathrm{a}$ & $132.4 \mathrm{a}$ & $2,766 \mathrm{a}$ & $0.51 \mathrm{a}$ \\
\hline $50 \mathrm{DAE}$ & $7.72 \mathrm{a}$ & $97.8 \mathrm{a}$ & $2.11 \mathrm{a}$ & $123.5 \mathrm{a}$ & $2,716 \mathrm{a}$ & $0.54 \mathrm{a}$ \\
\hline & & & $2017 / 2018$ grow & season & & 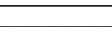 \\
\hline \multicolumn{7}{|l|}{ Cultivar ${ }^{1}$} \\
\hline BRS 1074 IPRO & $9.64 \mathrm{a}$ & $58.0 \mathrm{a}$ & $1.42 \mathrm{a}$ & $110.2 \mathrm{a}$ & $1,883 \mathrm{a}$ & $0.37 \mathrm{a}$ \\
\hline ST 797 IPRO & $9.25 \mathrm{a}$ & $60.7 \mathrm{a}$ & $1.41 \mathrm{a}$ & $99.3 \mathrm{~b}$ & $1,714 b$ & $0.34 \mathrm{~b}$ \\
\hline \multicolumn{7}{|c|}{ Nitrogen application time ${ }^{2}$} \\
\hline Sowing & $9.38 \mathrm{a}$ & $59.5 \mathrm{a}$ & $1.42 \mathrm{a}$ & $102.4 \mathrm{a}$ & $1,868 \mathrm{a}$ & $0.36 \mathrm{a}$ \\
\hline $30 \mathrm{DAE}$ & $9.75 \mathrm{a}$ & $58.8 \mathrm{a}$ & $1.40 \mathrm{a}$ & $103.1 \mathrm{a}$ & $1,728 \mathrm{a}$ & $0.33 \mathrm{a}$ \\
\hline $50 \mathrm{DAE}$ & $9.21 \mathrm{a}$ & $59.7 \mathrm{a}$ & $1.43 \mathrm{a}$ & $108.8 \mathrm{a}$ & $1,799 \mathrm{a}$ & $0.37 \mathrm{a}$ \\
\hline
\end{tabular}

${ }^{1}$ Means followed by distinct letters in the column show significant differences by the F-test $(\mathrm{p} \leq 0.05) .{ }^{2}$ Means followed by distinct letters in the column show significant differences by the t-LSD test $(\mathrm{p} \leq 0.05) .{ }^{3} \mathrm{DAE}$ : days after the emergence. 
two soybean cultivars had a similar grain yield, but the ST 797 IPRO cultivar had more pods per plant and more grains per pod (Table 4).

The first pod height was similar between the two soybean cultivars in both growing seasons (Table 4). These results are due to the fact that the first pod height is an agronomic trait controlled mainly by the genetic factors of the cultivar, and that the two cultivars used in this study have a similar growth potential for height (Table 3). The first pod height is an important characteristic for adjustment to the mechanical harvest in soybean, and the grain loss could be increased when it is less than $12 \mathrm{~cm}$ (Sediyama 2013).

The $\mathrm{N}$ application times did not significantly affect $(\mathrm{p}>0.05)$ the production components and grain yield of the soybean crop in both growing seasons (Table 4). These results indicate that the application of $\mathrm{N}$ fertilizer at sowing or as topdressing (30 or 50 DAE) does not affect the main agronomic traits and grain yield of soybean. Similarly, Aratani et al. (2008) reported that the $\mathrm{N}$ fertilizer application at sowing or 30 DAE do not interfere in the production components (pods per plant, grains per pod and 1,000-grain mass) and grain yield of soybean. Moreno et al. (2018) also verified that the $\mathrm{N}$ application at sowing or full flowering do not affect the first pod height and number of pods per plant; however, they observed that the application of $\mathrm{N}$ at sowing, combined with the application at full flowering, resulted in a greater 1,000-grain mass and soybean yield.

The greater proximity of the application of $\mathrm{N}$ fertilizer to the period of pod development (R3 to R5 stage), as occurred in this study with the application at $50 \mathrm{DAE}$, has been recommended by some Brazilian researchers to potentiate the grain filling and yield performance of soybean. This late $\mathrm{N}$ fertilization does not affect the nodulation process of soybean, as it occurs with the starter $\mathrm{N}$ applications. However, the $\mathrm{N}$ application at $50 \mathrm{DAE}$ did not prove to be an effective agronomic practice to increase the grain mass and soybean yield, when the seeds are inoculated with efficient strains of B. japonicum. Therefore, this practice should not be recommended for Brazilian farmers, and new studies should be conducted to investigate its effectiveness in the different regions of soybean production, in association with the inoculation of B. japonicum.

The lack of response to the $\mathrm{N}$ application time on the assessed agronomic traits may be attributed to the fact that all the crop requirements for this nutrient were supplied by the atmospheric nitrogen $\left(\mathrm{N}_{2}\right)$ fixed through the soybean-Bradyrhizobium symbiosis, and by mineral $\mathrm{N}$ from the soil. About this, in addition to the known efficacy of this biological N-fixing process, it is possible to add the high efficiency of the Bradyrhizobium strains used in Brazil, and their high competitiveness with microorganisms native to these tropical soils (Hungria \& Mendes 2015). Also, initial soil organic matter contents (Table 1) were sufficient to provide about $50-65 \mathrm{~kg} \mathrm{ha}^{-1}$ of $\mathrm{N}$ for the soybean crop, as supported by Sousa \& Lobato (2004). This relatively high supply of $\mathrm{N}$ for soybean plants, from the mineralization of soil organic matter, may be associated with the fact that the experiment was carried out in a soil that had been cultivated for twelve years with Urochloa sp. The cropping of species of the Urochloa sp. genus has been highlighted in the Brazilian tropical Savannah sandy soils, due to the high capacity of dry matter production, drought tolerance and high capacity to recycle nutrients in the soil profile (Bressan et al. 2013, Janegitz et al. 2016). Therefore, these species have been widely used as cover crops during the fall/winter in Brazil, and are good alternatives to improve the soil fertility and nutrient use efficiency of subsequent crops. In this study, the soybean crop was benefited by the improvement of the soil chemical conditions (Table 1) promoted by the previous and long cultivation of Urochloa sp. pasture.

The $\mathrm{N}$ fertilizer rates did not significantly affect $(\mathrm{p}>0.05)$ the production components and grain yield of soybean in both seasons, except for the 1,000-grain mass, in the 2017/2018 growing season (Figure 3). These results indicate that rates of $\mathrm{N}$ fertilization up to $60 \mathrm{~kg} \mathrm{ha}^{-1}$ could not improve the agronomic characteristics of the soybean cultivars, including the grain yield. Similar results were reported by Korber et al. (2017), who showed that application rates of up to $80 \mathrm{~kg} \mathrm{ha}^{-1}$ of $\mathrm{N}$ do not affect the agronomic characteristics and grain yield of the soybean. Kaschuk et al. (2016) also demonstrated that the application of up to $50 \mathrm{~kg} \mathrm{ha}^{-1}$ of $\mathrm{N}$ do not improve the soybean yield. This reinforces that the $\mathrm{N}$ requirement of the crop was supplied by mineralized $\mathrm{N}$ from the soil organic matter and by biological $\mathrm{N}$ fixation.

The 1,000-grain mass, in the 2017/2018 growing season, increased progressively with the increase in the rates of $\mathrm{N}$ fertilizer application 
(Figure 3d). Petter et al. (2012) showed that the application of $20 \mathrm{~kg} \mathrm{ha}^{-1}$ and $40 \mathrm{~kg} \mathrm{ha}^{-1}$ of N increased the average of this trait in soybean, when compared to the unfertilized treatment. Similarly, Moreno et al. (2018) also demonstrated that the application rates of $40 \mathrm{~kg} \mathrm{ha}^{-1}$ and $60 \mathrm{~kg} \mathrm{ha}^{-1}$ of $\mathrm{N}$ resulted in a greater 1,000-grain mass for the soybean crop. A large amount of $\mathrm{N}$ is extracted and exported by the soybean crop (Kaschuk et al. 2016), since its grain is constituted by $36-40 \%$ of protein (i.e., a $\mathrm{N}$ macromolecule). Therefore, the increase of grain weight with the application of $\mathrm{N}$ rates was already expected. However, when the $\mathrm{N}$ rates were applied in a year with the highest rainfall rate, as in the 2016/2017 growing season, there were no significant effects of the $\mathrm{N}$ fertilizer rates on the 1,000-grain mass (Figure 3d). These results may be due to the higher soybean nodulation observed in this growing season, if compared to the 2017/2018 season (Figures 2c and $2 d)$. This higher nodulation in the 2016/2017 season was able to supply all the $\mathrm{N}$ demand of the crop, leaving the soybean less dependent on the $\mathrm{N}$ applied by the chemical $\mathrm{N}$ fertilizer.

The average soybean yield in the 2016/2017 growing season was $2,807 \mathrm{~kg} \mathrm{ha}^{-1}$, while, in the $2017 / 2018$ season, it was $1,780 \mathrm{~kg} \mathrm{ha}^{-1}$ (Figure 3e). The lower grain yield obtained in the 2017/2018 season was due to the lower rainfall (Figure 1). The low water availability in the soil for the plants is one of the most critical environmental factors that limit plant growth and grain yield for the soybean crop in Brazil and other areas of the world (MertzHenning et al. 2018). Also, the lower grain yield in both crops, when compared to the average grain yield of soybean in Brazil $\left(3,360 \mathrm{~kg} \mathrm{ha}^{-1}\right)$, may be attributed to the fact that this study was carried out in an area without previous soybean cultivation. In soils of first cultivation, where there are still no specific populations of rhizobia to establish the symbiosis, the initial nodulation delay caused by the $\mathrm{N}$ fertilizer at sowing leads to a lower potential of crop production, in relation to that from established areas, with several growing seasons of soybean crops (Embrapa 2011).

In summary, our results showed that it is possible to obtain high soybean yields without supplying $\mathrm{N}$ fertilizer, corroborating the results shown by Aratani et al. (2008), Kaschuk et al. (2016) and Korber et al. (2017). This lack of response of the soybean crop to the $\mathrm{N}$ fertilization may be attributed to the higher amount of mineralized $\mathrm{N}$ of the soil organic matter from the consecutive years of Urochloa sp. cultivation, which improved the chemical properties of the soil. In addition, currently Brazilian soybean producers adopt the inoculation of Bradyrhizobium sp. as the main source of $\mathrm{N}$ for the plants, since it is an efficient practice, with a low economic cost, when compared to the use of mineral $\mathrm{N}$ fertilizer.

\section{CONCLUSION}

The use of nitrogen fertilizer up to $60 \mathrm{~kg} \mathrm{ha}^{-1}$ does not improve the production components and does not increase the soybean grain yield, regardless of the rates and times of application. Therefore, when efficient strains of Bradyrhizobium japonicum are used in areas of first soybean crop, in a Quartzipsamment soil with medium-high fertility, especially with a long record of Urochloa sp. cultivation, there is no need to apply starter or late rates of $\mathrm{N}$ fertilizer.

\section{ACKNOWLEDGMENTS}

To the Coordenação de Aperfeiçoamento de Pessoal de Nível Superior (Capes), for the post-doctoral fellowship (project n ${ }^{\circ} 51004011007 \mathrm{P} 8-\mathrm{PNPD}$ ) granted to the first author.

\section{REFERENCES}

ARATANI, R. G. et al. Adubação nitrogenada em soja na implantação do sistema plantio direto. Bioscience Journal, v. 24 , n. 3, p. 31-38, 2008.

BARRANQUEIRO, H. R.; DALCHIAVON, F. C. Aplicação de azoto na cultura da soja. Revista de Ciências Agrárias, v. 40, n. 1, p. 196-204, 2017.

BRESSAN, S. B. et al. Plantas de cobertura e qualidade química de Latossolo Amarelo sob plantio direto no Cerrado maranhense. Revista Brasileira de Engenharia Agrícola e Ambiental, v. 17, n. 4, p. 371-378, 2013.

CEREZINI, P. et al. Water restriction and physiological traits in soybean genotypes contrasting for nitrogen fixation drought tolerance. Scientia Agricola, v. 74, n. 2 , p. 110-117, 2017.

DOMINGOS, C. S.; LIMA, L. H. S.; BRACCINI, A. L. Nutrição mineral e ferramentas para o manejo da adubação na cultura da soja. Scientia Agraria Paranaensis, v. 14, n. 3, p. 132-140, 2015. 
EMPRESA BRASILEIRA DE PESQUISA AGROPECUÁRIA (Embrapa). Tecnologias de produção de soja: região central do Brasil. Londrina: Embrapa Soja, 2011.

FELISBERTO, G. et al. Agronomic performance of RR soybean cultivars using different pre-sowing desiccation periods and distinct post-emergence herbicides. African Journal of Agricultural Research, v. 10, n. 34, p. 34453452, 2015.

FERREIRA, D. F. Sisvar: a computer statistical analysis system. Ciência e Agrotecnologia, v. 35, n. 6, p. 10391042, 2011.

GILLER, K. E.; WILSON, K. J. Nitrogen fixation in tropical cropping systems. Wallingford: CAB, 1991.

HUNGRIA, M.; MENDES, I. C. Nitrogen fixation with soybean: the perfect symbiosis? In: BRUIJN, F. (Ed.). Biological nitrogen fixation. New Jersey: John Wiley \& Sons, 2015.

JANEGITZ, M. C. et al. Brachiaria as a cover crop to improve phosphorus use efficiency in a no-till Oxisol. Revista Brasileira de Ciência do Solo, v. 40, e0150128, 2016.

KASCHUK, G. et al. Differences in photosynthetic behavior and leaf senescence of soybean (Glycine max [L.] Merrill) dependent on $\mathrm{N}_{2}$ fixation or nitrate supply. Plant Biology, v. 12, n. 1, p. 60-69, 2010.

KASCHUK, G. et al. Response of determinate and indeterminate soybean cultivars to basal and topdressing $\mathrm{N}$ fertilization compared to sole inoculation with Bradyrhizobium. Field Crops Research, v. 195, n. 1, p. 21-27, 2016.

KORBER, A. H. C. et al. Adubação nitrogenada e potássica em soja sob sistemas de semeadura. Revista de Agricultura Neotropical, v. 4, n. 4, p. 38-45, 2017.

LIMA, I. P. et al. Performance of conventional and transgenic soybean cultivars in the south and Alto Paranaiba regions of Minas Gerais, Brazil. American Journal of Plant Science, v. 6, n. 9, p. 1385-1390, 2015.

MCCOY, J. M. et al. Nitrogen fertilization of soybean affects root growth and nodulation on two soil types in Mississippi. Communications in Soil Science and Plant Analysis, v. 49, n. 2, p. 181-187, 2018.
MENDES, I. C. et al. Adubação nitrogenada suplementar tardia em soja cultivada em Latossolos do Cerrado. Pesquisa Agropecuária Brasileira, v. 43, n. 8, p. 10531060, 2008.

MERTZ-HENNING, L. M. et al. Effect of water deficitinduced at vegetative and reproductive stages on protein and oil content in soybean grains. Agronomy, v. 8, n. 3, p. 2-11, 2018.

MORENO, G. et al. Application of nitrogen fertilizer in high-demand stages of soybean and its effects on yield performance. Australian Journal of Crop Science, v. 12, n. 1, p. 16-21, 2018.

PARENTE, T. L. et al. Adubação nitrogenada em genótipos de soja associada à inoculação em semeadura direta no Cerrado. Revista Brasileira de Ciências Agrárias, v. 10, n. 2, p. 249-255, 2015.

PETTER, F. A. et al. Respostas de cultivares de soja à adubação nitrogenada tardia em solos de Cerrado. Revista Caatinga, v. 25, n. 1, p. 67-72, 2012.

SAITO, A. et al. Effect of nitrate on nodule and root growth of soybean (Glycine max (L.) Merr.). International Journal of Molecular Sciences, v. 15, n. 3, p. 4464-4480, 2014.

SANTOS, H. G. et al. Sistema brasileiro de classificação de solos. 3. ed. Brasília, DF: Embrapa, 2013.

SEDIYAMA, T. Tecnologia de produção de sementes de soja. Londrina: Mecenas, 2013.

SOARES, I. O. et al. Interaction between soybean cultivars and seed density. American Journal of Plant Science, v. 6, n. 9, p. 1425-1434, 2015.

SOUSA, D. M. G.; LOBATO, E. (Eds.). Cerrado: correção do solo e adubação. 2. ed. Brasília, DF: Embrapa Informação Tecnológica, 2004.

TAIZ, L. et al. Fisiologia e desenvolvimento vegetal. 6. ed. Porto Alegre: Artmed, 2017.

UNITED STATES DEPARTMENT OF AGRICULTURE (USDA). Keys to soil taxonomy. 12. ed. Washington, DC: USDA-Natural Resources Conservation Service, 2014.

ZUFFO, A. M. et al. Microbiological attributes in a Latosol in glyphosate application under water deficit conditions. African Journal of Agricultural Research, v. 9, n. 32, p. 2495-2505, 2014. 